\title{
Fémhabstruktúrák elemzése és geometriai modellezése
}

\author{
T. A. VARGA ${ }^{1}$, T. MANKOVITS ${ }^{2}$ \\ 1Debreceni Egyetem, varga.tamas@eng.unideb.hu \\ 2Debreceni Egyetem, tamas.mankovits@eng.unideb.hu
}

\begin{abstract}
Absztrakt. A mérnöki kutatások egyik nagy kihívása a mára már széles körben alkalmazott fémhabok geometriai modellezése, valamint a megalkotott 3D-s modell numerikus szilárdságtani vizsgálata. A fémhab struktúrája meglehetősen bonyolult, így a valóságot jól megközelítő CAD modell elóállítása önmagában is komoly mérnöki feladat, annak adott terhelésre történő végeselemes szimulációja pedig a kutatások középpontjában áll. A projekt ezen részének célja az előzőekben tárgyalt témakörökre vonatkozó nemzetközi szakirodalom kritikai elemzése és az eredmények adaptálási lehetőségei, továbbá egy térfogatelemzési eljárás bemutatása a fémhab celláival kapcsolatban.
\end{abstract}

Abstract. The development of an efficient procedure for 3D modelling and finite element simulation of metal foams is one of the greatest challenges to engineer researchers nowadays. Creating 3D CAD model is alone a demanding engineering task due to its extremely complex geometry, and the proper finite element analysis process is still in the center of the research. The aim of this project is to analyze the related literature and to adapt the results may be considered.

\section{Bevezetés}

A fémhab viszonylag régóta ismert, de ipari és orvosi alkalmazása csak az elmúlt pár évben kezdett széles körben elterjedni. Ez annak köszönhető, hogy mára már megbízható eljárások léteznek a gyártási technológiára, amely technológia eredményeképpen szabályozható az előálításra kerülő fémhab belső szerkezete. Köztudott, hogy a fémhaboknak kicsi a sűrűsége, de ennek ellenére kiváló mechanikai és fizikai tulajdonságokkal rendelkeznek. Emellett számos olyan pozitív tulajdonságuk van, amelynek eredményeként nemcsak rezgés-, vagy ütközéscsillapításra alkalmasak, hanem teherviselő elemként (járműalkatrészként, protézisként) is kiválóan hely tállnak. Számos tanulmány foglalkozott és számolt be a fémhabok alkalmazási lehetőségeiről, amelyekből jól látható, hogy a mérnöki és orvosi alkalmazásuk rohamosan terjed, és egyértelműen a jövő egyik meghatározó anyagtípusává válnak. Teherviselő fémhabok esetén különösen előtérbe kerül a terméktervezési folyamat problematikája, amelynek központi kérdése a geometriai modellezés és a numerikus szimuláció. Teherviselő anyagként azt várjuk a fémhabtól, hogy az alkalmazás során rugalmasan viselkedjen, így megfelelő biztonsággal kell ismernünk, vagy képeseknek kell lennünk megbecsülni az anyagunk válaszát az adott terhelésre. Annak érdekében, hogy egy geometriai modellt tudjunk előállítani a fémhabról, ami egy komoly mérnöki feladat, kellő információval kell rendelkeznünk annak 
DOI: 10.21791/IJEMS.2016.2.19.

a belső szerkezetéről. A fémhabok fizikai és mechanikai tulajdonságai közvetlenül függnek a fémhab struktúrájától és sztochasztikus jellegétől. Mivel a fémhabok belső szerkezete meglehetősen bonyolult, így felületelemzéssel csak hiányos, sok esetben pedig félrevezető információhoz juthatunk.

Jelenleg leghatékonyabban CT berendezéssel lehet meghatározni a fémhabok belső struktúráját. Ez az eljárás nagyon hatékony, de egyben elég komplex feladatot ad az ebből kidolgozni kívánt modell előállítása. Az eljáráshoz CT berendezésre van szükségünk, amely nem mindig áll rendelkezésre, illetve az ilyenfajta modellalkotásnak komoly számítási igénye van, amelyet egy átlagos teljesítményű számítógép nem képes elvégezni. Kijelenthető, hogy ez ma a legkorszerűbb olyan eljárás, amely segítségével pontos információkhoz juthatunk a vizsgált szerkezetünk belsejéről is.

Jelen cikk főleg a nemzetközi szakirodalomban fellelhető fémhab modellezési lehetőségekről kíván számot adni. Továbbá bemutatni kívánunk egy újszerű struktúra elemzési eljárást a fémhab celláival kapcsolatban.

\section{Fémhabok modellezési lehetőségei}

A fémhab geometriai modellezését alapvetően kétféle stratégiával lehet megvalósítani. Az egyik az, amikor a komputertomográf felvételekből generált statisztikai adatokból felépítünk egy olyan idealizált modellt, amely hasonlóan viselkedik terhelés hatására, mint az eredeti. A másik lehetőség az, hogy a legyártott fémhabról készült CT felvételek segítségével építjük fel a valós geometriai modellt. Mindkét eljárásnak van előnye és hátránya is. Az idealizált modell előnye, hogy néhány előre meghatározott adatból képesek vagyunk felépíteni egy modellt, de a nagy hátránya az, hogy csak megközelítőleg tudjuk szimulálni a fémhab reakcióját, hiszen ez a 3D-s modell nem teljesen egyezik meg a legyártott próbatesttel. A CT felvételnek nagy előnye, hogy ugyanazt a 3D-s geometriát tudjuk vizsgálni, mint a vizsgált fémhab. Hátránya, hogy a gyártástechnológiából fakadó nehéz reprodukálhatóság miatt csak a konkrét fémhab szerkezetre tudunk információt szolgáltatni. Mindkét eljáráshoz szükséges tehát egy olyan drága berendezés, amely nem mindenhol érhető el. Jelenleg sok idealizált modell létezik, de ezek egyike se szolgál teljesen pontos eredményekkel. CT alapú modellalkotással és rekonstrukcióval is számos kutató próbálkozik, de senkinek sem sikerült egy olyan modellalkotási eljárást kifejleszteni, amely mindennapokban használható lehetne.

\section{Fémhabok modellezési lehetőségei}

A fémhab geometriai modellezését alapvetően kétféle stratégiával lehet megvalósítani. Az egyik az, amikor a komputertomográf felvételekből generált statisztikai adatokból felépítünk egy olyan idealizált modellt, amely hasonlóan viselkedik terhelés hatására, mint az eredeti. A másik lehetőség az, hogy a legyártott fémhabról készült CT felvételek segítségével építjük fel a valós geometriai modellt. Mindkét eljárásnak van előnye és hátránya is. Az idealizált modell előnye, hogy néhány előre meghatározott adatból képesek vagyunk felépíteni egy modellt, de a nagy hátránya az, hogy csak megközelítőleg tudjuk szimulálni a fémhab reakcióját, hiszen ez a 3D-s modell nem teljesen egyezik meg a legyártott próbatesttel. A CT felvételnek nagy előnye, hogy ugyanazt a 3D-s geometriát tudjuk vizsgálni, mint a vizsgált fémhab. Hátránya, hogy a gyártástechnológiából fakadó nehéz 
DOI: 10.21791/IJEMS.2016.2.19.

reprodukálhatóság miatt csak a konkrét fémhab szerkezetre tudunk információt szolgáltatni. Mindkét eljáráshoz szükséges tehát egy olyan drága berendezés, amely nem mindenhol érhető el. Jelenleg sok idealizált modell létezik, de ezek egyike se szolgál teljesen pontos eredményekkel. CT alapú modellalkotással és rekonstrukcióval is számos kutató próbálkozik, de senkinek sem sikerült egy olyan modellalkotási eljárást kifejleszteni, amely mindennapokban használható lehetne.

\section{A CT vizsgálat eredményeinek feldolgozása}

A CT berendezés az egyedüli méréstechnikai eszköz, amellyel olyan térfogat-információ szerezhető a vizsgált alkatrészről, ami nemcsak a külső burkolófelület topológiáját határozza meg nagy pontossággal, hanem adatot szolgáltat a belső struktúráról, inhomogenitásról is [1]. Napjainkban a CT berendezéseket számos vizsgálathoz alkalmazzák. Az egyik legismertebb alkalmazási területi az orvostudomány, de számos műszaki alkalmazási területe van. A CT berendezés 2D-s felvételt készít az adott munkadarabról, majd a munkadarabot az asztallal együtt egy bizonyos szögben elfordítja, és újabb felvételt készít róla (1. ábra). Ez addig folytatódik, amíg az adott munkadarab teljesen körbe nem fordul. Az alkatrész ellentétes oldalán elhelyezett detektor érzékeli a különböző röntgen intenzitást. A vizsgálat elvégzése után rendelkezésünkre áll minden egyes egységnyi szögelfordulás után egy 2D-s kép. Az általunk vizsgált fémhabról készített CT felvétel az 1. ábrán látható.

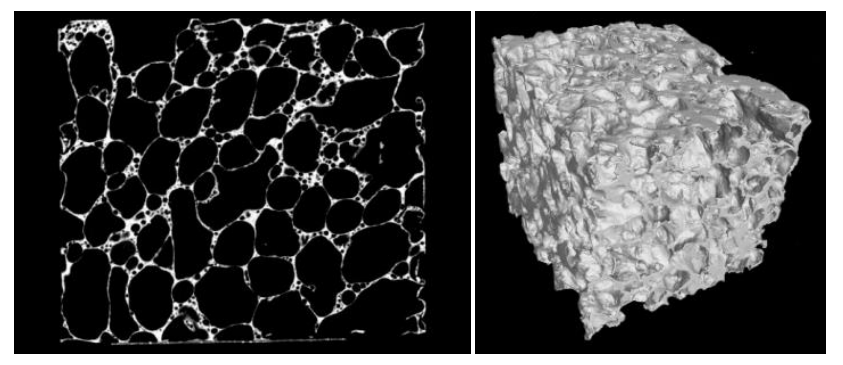

1. ábra: Általunk készített CT felvétel és modell

A CT vizsgálat után rendelkezésre áll számos 2D-s felvétel, amelyeket általában a CT berendezéshez kapott szoftverrel lehet összeállítani, hogy egy 3D-s modellt kapjunk. Ezek a 3D-s modellek .stl kiterjesztésűek, amelyek voxel elemekből állnak és ez csak vizuális megjelenítésre alkalmasak. A voxel háromdimenziós képi elem, mind a három tengely mentén kiterjedéssel bíró pontegység, mint térfogat-képalkotási eszköz, standard az orvosi diagnosztikában. Ezzel ellentétben, a műszaki gyakorlatban a burkolófelületet leíró hálót (.dxf), vagy térfogati elemet alkalmaznak (.iges), tehát az eredeti voxel modellt át kell alakítani. Azonban ezeken a modelleken, CT felvételeken keletkeznek hibák, zajok, amelyeket el kell tüntetni a felvételekről, továbbá a létrehozott modell sem egységes, ezért rekonstruálni kell azokat. Ezeket az eljárásokat számos szoftverrel el lehet végezni.

Nyílt cellás alumíniumhabot, illetve nikkelhabot vizsgál Michailidis és szerzőtársai [2]-ben. A

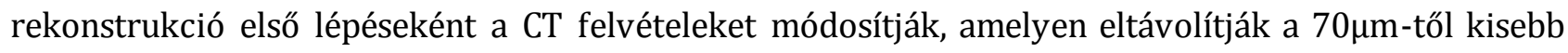
méretű pontokat. Ezt követően létrehoznak egy 3D-s térfogat modellt (.iges kiterjesztés) amely térfogatelemekből áll. Sajnos a cikkben nem említik a rekonstrukcióhoz használt szoftvert. A 3D-s modellnek a mérete 7.3x6.1x1.4 mm, amelyet a nagy alakváltozás miatt az Ansys végeselem szoftver NLGEOM funkcióját használják. 
DOI: 10.21791/IJEMS.2016.2.19.

A [3]-ban a szerzők zártcellás alumíniumhabot vizsgálnak. A CT által elkészített 2D-s képeket MATLAB szoftverrel rekonstruálják. A rekonstrukció első lépéseként a CT felvételekből bináris képet készítenek, majd ezeken eltávolítják a tévesen érzékelt pontokat. Ezt követően meghatározzák a cellák határvonalait, ezáltal pontosítva a képeket. Ebben a cikkben 2D-s modellekkel dolgoznak, míg [4]-ben már egy Ø14x5 mm nagyságú modellen végzik a vizsgálataikat. A végeselem vizsgálathoz az ABAQUS szoftvert használják.

Ramirez és szerzőtársai szintén nyílt cellás alumíniumhabot vizsgálnak [5]-ben. A CT felvételek rekonstrukciójához a MIMICS trial verzióját használják. Ezt követően a modellre végeselem hálót generálnak az ABAQUS szoftver segítségével, amivel el is végzik a végeselem vizsgálatot. Az általuk használt modell a próbatestből kivágott keskeny kis darabka.

A [6]-ban nyílt cellás M-Pore ${ }^{\circledR}$ és zárt cellás Alporas® alumíniumhabokat vizsgálnak. A 3D rekonstrukciót a phoenix datos|x nevezetű szoftverrel végzik el, majd ezt követôen a végeselem vizsgálatot a MSC.Marc szoftverrel. Az általuk generált modellek nagysága 14x14x14 mm illetve $28 \times 28 \times 28 \mathrm{~mm}$.

Zárt cellás ALPORAS alumíniumhabot vizsgálnak a [7]-ben. A rekonstrukcióhoz Octopus 8.1 szoftvert használnak. A végeselem vizsgálathoz 50×50x5.5 mm és 50×50×13.5 mm nagyságú modelleket használnak.

A [8]-ban zárt cellás ALPORAS alumíniumhabot vizsgálnak. Maga a CT felvételek rekonstrukciójához TRI/3D-BON of Ratoc System Engineering Co. Ltd. szoftvert használtak. Ezt követően a röntgen filmeket RapidForm of INUS szoftverrel illesztették össze, amelyből 3D-s felületi modellt alkottak. Ezután a végeselemes hálót hozták létre a PATRAN of MSC programmal. A végeselem vizsgálatot ABAQUS programmal végezték el. A végeselem vizsgálatot $5 \times 5 \times 5$ mm-es modellen végezték el.

A fentiekből látható, hogy számos lehetőség van a fémhabok modellezésére, valamint ahhoz számos szoftvert használnak sikeresen. Észrevehető az is, hogy leginkább kis méretű modelleket használnak, mivel egy ekkora modell rekonstrukciója, illetve végeselem szimulációja is sok ideig tart. Jelenlegi kutatásunk középpontjában áll egy olyan rekonstrukciós eljárás kifejlesztése, amellyel egy CT felvételből végeselem hálót tudjunk előállítani. A modell rekonstrukciójáról egy példa látható a 2 . ábrán. A rekonstrukció eredményeiről jelenlegi cikkünkben nem kívánunk beszámolni.

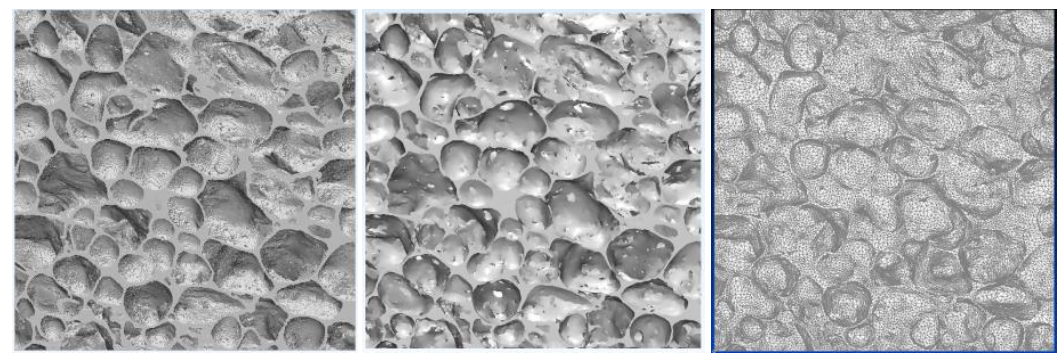

2. ábra: Modell változása a rekonstrukció során 


\section{Térfogatelemzés CT felvételek alapján}

A CT felvételek alapján a fémhab próbatesteken porozitás vizsgálatot lehet elvégezni egy célszoftver segítségével, amellyel meghatározhatóak a fémhab modelleket felépítő cellák adatai. A kiértékelő szoftverbe a próbatestekről készült CT felvételek kerülnek importálásra, majd a szoftver ezeket feldolgozza, tehát elmondható, hogy az eredeti CT képekkel dolgozik, azokat nem alakítja át, így az eljárás hitelesnek mondható. Számunkra a következő adatok bizonyulhatnak hasznosnak:

- Cella körülírható gömbjének átmérője

- Cella középpontja (XYZ koordinátarendszerben)

- Cella térfogata

- Cella felülete

- Két cella közötti legkisebb távolság

- Cella gömbisége

- Cellát körülírható téglatest méretei (XYZ méretek)

Ezen adatok hasznosnak bizonyulnak a fémhabstruktúrák elemzésében. A szoftver által meghatározott adathalmazból a későbbiekben lehetőségünk nyílik jobban megismerni a fémhabunk struktúráját, és ez a későbbiekben hasznos lehet egy idealizált modell felépítéséhez is. A vizsgálatból látható majd, hogy a fémhabstruktúránk teljesen rendezetlen cellákból állnak. Ez a legfőbb ok, amiért nehéz modellezni a fémhabstruktúrát idealizált modellekkel, és ezért előnyös CT alapú valós modelleket használni, és azokat szimulálni.

A térfogatelemző szoftver alkalmas vizuális megjelenítésre is (3. ábra), amelyben láthatjuk az adott cellák helyét, és alakját. Itt jól látható, hogy az analizált cellák térfogatának nagyságát színskálával látja el a szoftver, így szemmel látható az cellák nagysága. A cellák metszeti képeit is láthatjuk, amelyből következtetni tudunk az cella alakjára, illetve a próbatesten belül való elhelyezkedésére.
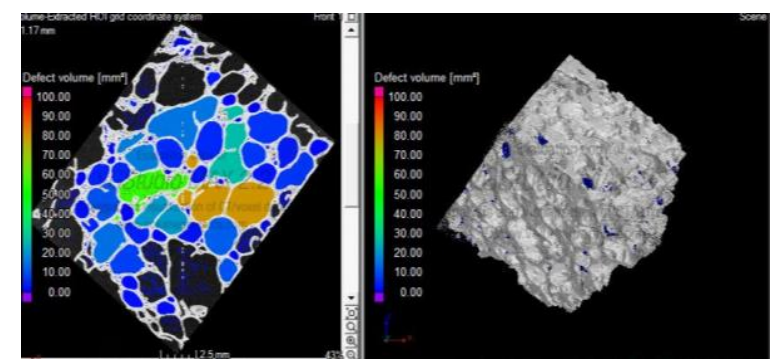

3. ábra: Térfogatelemzés által meghatározott cellák

A következőekben a vizsgálati eljárás által meghatározott adatokat kívánom bemutatni egy próbatesten. A térfogatelemző szoftver a próbatesten 185 cellát detektált, és meghatározta az általunk meghatározni kívánt adatokat. A szoftver csak az 1 mm3-nél nagyobb cellákat vizsgálta. 


\subsection{Cellák térfogatának eloszlása}

A fémhab számos cellából épül fel, amelyek jelen gyártási technológiának köszönhetően nem azonos alakúak és méretűek. Az idealizált modell kialakításához ezekről a cellákról minél több információt kell megtudnunk, hogy komplex képet kapjunk a fémhabunk struktúrájáról. A térfogatelemző szoftverünk segítségével lehetőségünk van ezeknek a celláknak a térfogatát meghatározni. A 4. ábrán láthatjuk a fémhabot felépítő cellák térfogateloszlását.

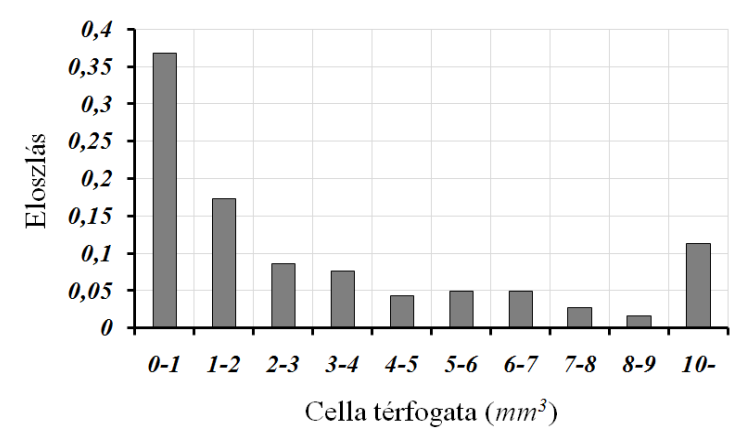

4. ábra: Cellák térfogatának eloszlása

\subsection{Cellaátmérők eloszlása}

A térfogatelemző szoftver képes meghatározni a cellát körülíró kör átmérőjének nagyságát meghatározni. Ez az átmérő egyben az cella két legszélsőbb pontjának távolsága. Ezeknek az átmérőknek az eloszlását az 5. ábrán láthatjuk.

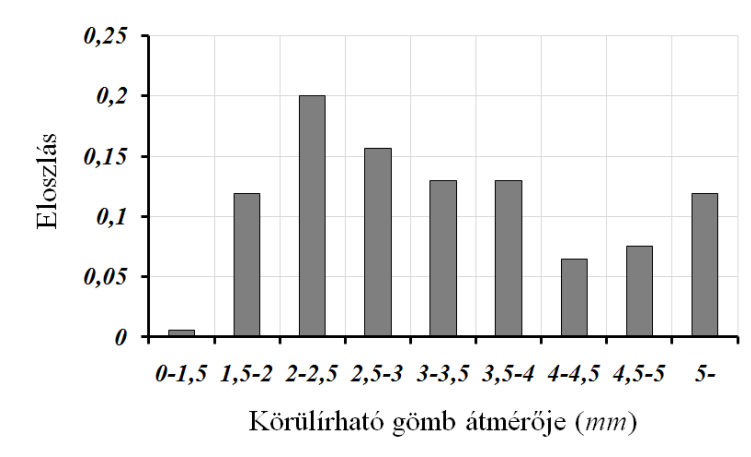

5. ábra: Cellát körülíró gömb átmérőjének eloszlása

\subsection{Cellák gömbisége}

A fémhabunkban lévő cellák nem szabályos gömb alakúak, így érdemes megvizsgálni ezeknek a celláknak a szabályosságát, gömbiségét. A gömbiség egy arányszám, amely annak az értéke, hogyan aránylik az cella térfogata a cellát körülíró gömb térfogatához. Ezzel megkapjuk, hogy az általunk vizsgált cellák mennyire szabályosak. A 6. ábrán láthatjuk ezen arányszámok eloszlását. 


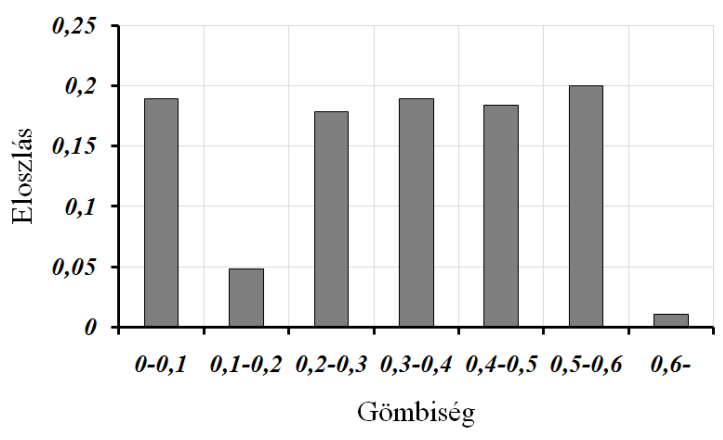

6. ábra: Cellák gömbiségének eloszlása

\section{Térfogatelemzés CT felvételek alapján}

Amint látható számos lehetősége van a fémhabok modellezésének. A modellezési stratégia kialakításánál el kell dönteni, hogy a statisztikai adatokból felépített idealizált modellt használunk, vagy a valós modellt próbáljuk felépíteni. Az mindenképp kijelenthető, hogy a legpontosabb eredményt a CT felvételek alapján alkotott geometriai modell nyújtja.

A CT felvételek alapján megvizsgáltuk a fémhab belső struktúráját és elemeztük azt. A vizsgálat során meghatároztuk a fémhab celláinak nagyságát, elhelyezkedését. A vizsgálat során arra a következtetésre jutottunk, hogy a fémhabot felépítő cellák nem szabályos gömb alakúak, így a modell geometriáját nehezen lehet gömb elemekből felépíteni.

A Debreceni Egyetem kutatói az utóbbi években komoly eredményeket értek el a fémhabok geometriai modellezésében és numerikus szilárdságtani vizsgálataiban.

\section{Köszönetnyilvánítás}

A publikáció elkészítését az Emberi Erőforrások Minisztériuma megbízásából az Emberi Erőforrás Támogatáskezelő által 2015-ben meghirdetett „Egyedi fejlesztést biztosító ösztöndíjak” (NTP-EFÖ-P15) című pályázati kiírása alapján a Nemzeti Tehetség Program támogatta.
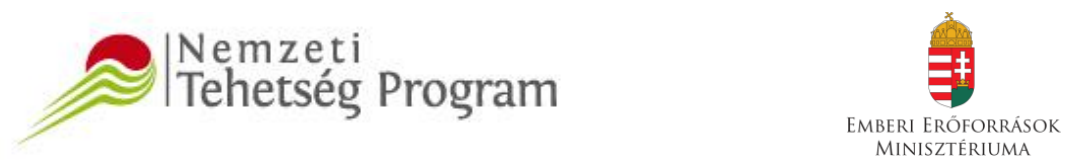

\section{Hivatkozások}

[1] I. Kozma, A komputertomográf ipari alkalmazásai, "A jövő járműve járműipari innováció 2006", Győr, Hungary, Volume 5/3-4, p. 8-11..

[2] N. Michailidis, F. Stergioudi, H. Omar, D. Papadopoulos, D.N. Tsipas, Experimental and FEM analysis of the material response of porous metals imposed to mechanical loading, „Colloids and Surfaces A: Physicochem. Eng. Aspects” 382 (2011) 124-131. 
[3] X., Zhu, S. Ai, D. Fang, B. Liu, X. Lu, A novel modeling approach of aluminum foam based on MATLAB image processing, Computational Materials Science" 82 (2014) 451-456.

[4] X. Zhu, S. Ai, X. Lu, X. Ling, L. Zhu, B. Liu, Thermal conductivity of closed-cell aluminum foam based on the 3D geometrical reconstruction, „International Journal of Heat and Mass Transfer" 72 (2014) 242-249.

[5] J. F. Ramírez, M. Cardona, J.A. Velez, I. Mariaka, J.A. Isaza, E. Mendoza, S. Betancourt, P. Fernández-Morales, Numerical modeling and simulation of uniaxial compression of aluminum foams using FEM and 3D-CT images, „Procedia Materials Science” 4 ( 2014 ) $227-231$.

[6] C. Veyhl, I.V. Belova, G.E. Murch, T. Fiedler, Finite element analysis of the mechanical properties of cellular aluminium based on micro-computed tomography, „Materials Science and Engineering" A 528 (2011) 4550-4555.

[7] M. Saadatfar, M. Mukherjee, M. Madadi, G.E. Schro"der-Turk, F. Garcia-Moreno, F.M. Schaller, S. Hutzler, A.P. Sheppar, J. Banhart, U. Ramamurty, Structure and deformation correlation of closed-cell aluminium foam subject to uniaxial compressionm „Acta Materialia" 60 (2012) 3604-3615.

[8] I. Jeon, T. Asahina, K. Kang, S. Im, T. J. Lu, Finite element simulation of the plastic collapse of closed-cell aluminum foams with X-ray computed tomography, „Mechanics of Materials” 42 (2010) 227-236. 